Ropo, A., De Paoli, D. and Bathurst, R. (2017). Aesthetic leadership in the arts.

In Mumford, M. and Hemlin, S. (Eds). Handbook of Research on Leadership and

Creativity. Cheltenham, UK and Northampton, MA, USA: Edward Elgar, pp. 445-457.

http://dx.doi.org/10.4337/9781784715465

\title{
Aesthetic leadership in the arts
}

Arja Ropo, University of Tampere, Finland arja.ropo@tuni.fi

Donatella De Paoli, Norwegian Business School BI, Norway,

donatella.d.paoli@bi.no

Ralph Bathurst, Massey University, New Zealand, r.bathurst@massey.ac.nz

\section{Abstract}

This chapter addresses creative leadership in a creative domain, the arts and art organizations. In fact, one might even expect that leading creative work would call for creative ways of leading. We use an aesthetic approach to leadership to discuss the theme. By aesthetic we refer to sense-based perceptions, embodied ways of relating to each other, intuition, and emotions. We provide empirical examples of leadership aspects that are especially important in artistic contexts. The illustrations are from the performing arts, especially from the fields of music and theatre. Reflexive awareness, dwelling in senses, interrogating senses, and being tuned to the rhythm of the artistic process were found to be important. Listening, gazing, and embodied gestures are examples of aesthetic leadership practices. 


\section{Keywords}

Aesthetic leadership, embodiment, art organizations, orchestra, theatre, ensemble, senses, reflexivity, listening, gaze, gestures

\section{Introduction: Creative art work and aesthetic leadership}

Creative work is the essence and 'raison d'etre' of the arts. The description and definition of the arts since the 18th century draws on the art and artists seeking unique expressions. Artists tend to distinguish themselves from other creative fields by emphasizing that artistic work unfolds from their inner feelings, drives, thoughts, senses and abilities.

Creative work and leadership in the arts is characterized by high professional standards and competence as the art field entails skilled artists often with long training and typically long craft experience. There are both individualized artwork domains such as composing, painting, writing and performing and more organized artistic processes like orchestras, theaters, and art galleries as well as productions of artistic performances. In the organizational artwork contexts leadership becomes an important factor.

There is a stream of literature that addresses arts management (discussed in journals like International Journal of Arts Management since 1998 and The Journal of Arts Management, Law, and Society since 1992) where issues of producing performances, exhibitions and such are looked from a managerial perspective leaving the artistic process to the artists. This is typically the view also of the orchestra managers and other art administrators. They see their job well done if the artists can fully concentrate on their creative work (personal communication, Ropo). 
In this chapter we focus on the inner workings of an artistic organization, the very process of doing art as a relational process among artists. As examples, we describe how aesthetic leadership plays out in large symphony orchestras, in theatre performances and rehearsals, and in a music ensemble. Aesthetic approach to leadership differs from the more traditional leadership models in a number of ways. Epistemologically it goes beyond the traditional notion of cognitive and rational nature of knowledge that prevails in most leadership models by acknowledging that valuable knowledge develops also in and through the human bodies and lived experiences - of the leader and the followers alike. From an aesthetic perspective leadership takes place in embodied relationships between the leader and the followers through the human senses, listening, hearing, touch, taste and smell. Thus, aesthetic leadership involves sensuous perceptions, emotions and memories.

Acknowledgement of the sensing and experiencing bodies of leaders and followers has been found important to understand leadership relationships (Hansen, Ropo and Sauer, 2007; Koivunen and Wennes, 2011; Ladkin and Taylor 2010; Ropo and Parviainen, 2001; Ropo, Parviainen, and Koivunen, 2002; Ropo and Sauer, 2008; Sinclair, 2005). An aesthetic approach to leadership has been recently viewed as one of the established leadership trends (Dinh, Lord, Gardner, Meuser, Liden and Hu, 2014). By aesthetic we refer to 'felt meaning' and 'felt experience' (Hansen et al., 2007) rather than to art itself or beauty. Jennifer KatzBuonincontro (2011) identified four aesthetic aspects of leadership: emotional awareness and empathy, sensory and somatic attentiveness, interest in organizational beauty and promotion of moral purpose.

Aesthetic view of leadership builds on a broader discussion on organizational aesthetics that started already in the mid 1980s at the Standing Conference on Organizational Symbolism (SCOS). Antonio Strati (1989, 1992), Pascale Gagliardi (1990), Rafael Ramirez (1996), David 
White (1996) and Mauro Guillén (1997) are among the first contributors to this paradigmatically new approach to organizations and organizing.

Hassard, Holliday and Willmott's edited volume "Body and organization" (2000) paved the way to address aesthetic and embodied aspects of organizational life. Stephen Lindstead and Heather Höpfl $(2000,1)$ point out the essence of body and aesthetics in organization studies by saying that 'aesthetic approaches move in the spaces between the organization as regulatory (the Law) and as experience (the Body); between the cognitive and the sensory'.

One stream of aesthetics in leadership can be traced to earlier writings using the phrase that leadership is an art rather than science (Barnard, 1938; De Pree, 1989; Vaill, 1989). Most often, this has been a rhetorical statement referring to something unexplainable rather than a serious conceptual treatment of aesthetic leadership. However, Taylor and Karanian (2008) make the observation, that there has been a gradual movement over the years from using the idea of leadership as an art loosely, to more detailed consideration of the philosophy behind it.

It is not until the past ten years that aesthetic aspects of leadership apart from the aesthetic organization theory have been brought to empirical and conceptual scholarly consideration (Guillet de Monthoux, 2004; Guillet de Monthoux, Gustafsson, and Sjöstrand, 2007; Hansen et al., 2007; Ladkin, 2008; Ladkin and Taylor, 2010; Ropo and Parviainen, 2001; Ropo et al., 2002; Ropo and Sauer, 2008; Sinclair, 2005).

A recent special issue of Leadership (2010) was titled "Leadership as art". Ladkin and Taylor (2010b) say in their editorial that the articles in the special issue share three patterns or themes that seem particularly potent for re-conceptualizing leadership: embodiment, contradictions, and artistic sensibilities (236). The importance of the embodied nature of 
leadership as an aesthetic phenomenon is an overarching theme in the special issue. Leadership happens through the engagement and interactions of human bodies.

Aesthetic, embodied leadership has been found important especially in artistic work processes, such as theatres and orchestras (Biel-Missal, 2010; Koivunen, 2003; Koivunen and Wennes, 2010; Ropo et al., 2002; Ropo and Parviainen, 2001; Sauer, 2005). We would assume that not only in art and cultural contexts but also in other type of professional and knowledge intensive organizations people, while being social human beings, are engaged with their senses, emotions and body. Thus, the relevance of aesthetic leadership would not be limited to the art domain. Next, we will describe how aesthetic leadership plays out in various artistic contexts.

\section{Example 1: Aesthetic leadership in symphony orchestras: listening, judgment, embodiment} Koivunen and Wennes (2011) provide a review of leadership in symphony orchestras. They note that the majority of the studies have focused on the conductors, their authority, physical and mental fitness, ambitions, intelligence, communication skills, charisma and transformational style (52). Beyond these individual qualifications and focus on the leader figure, an aesthetic approach to leadership emphasizes the relational process between the leader and the led: what happens in the space between (Ladkin, 2010). Koivunen and Wennes studied the interaction between the conductor and the musicians: the process of leadership involving both the leader and the followers and its aesthetic aspects. They emphasize that the ongoing interaction between the conductor and the musicians makes the relational process visible: the response to the conductor's action is immediate (54). Köping (2007) went even further by noting that aesthetic leadership in symphony orchestras is created by "a circular response" instead of the conductor's authoritative view and power over the players. 
Based on qualitative studies of four symphony orchestras, Koivunen and Wennes concluded to three aesthetic leadership dimensions that they found the most critical in analyzing leadership in symphony orchestras: relational activities, such as listening, aesthetic judgment, and embodiment, especially kinesthetic empathy (57).

A layperson might expect that in a symphony orchestra rehearsal playing and talking about how to play would be the focal activities. However, it is common knowledge among the orchestra musicians (also personally experienced by the first author) that there is surprisingly little talk, but mostly listening to the sound. The musicians are keen on playing, not talking (personal communication, Ropo). Listening is a key relational activity while playing together (Koivunen, 2002; Ropo et al., 2002): each player listens to her own instrument and the next person's sound, followed by ongoing adjustment and response; the player also listens to the next instrument section's sound, and even the further section's sound and adjusts her playing to that. It is the conductor's responsibility to listen to the whole orchestra's sound to make the outcome enjoyable and faithful to the composer. Listening as an aesthetic quality of leadership does not refer here only to the physical hearing capacity, but entails intensive bodily presence, sensitivity to the environment, alertness and willingness to adhere or even surrender to fellow musicians (Koivunen and Wennes, 2011; Ropo and Sauer, 2008; Ropo et al., 2002; Soila-Wadman, 2007).

Aesthetic judgment is another aspect of leadership in an artistic organization (Ladkin, 2008; Koivunen and Wennes, 2011). While aesthetic judgment would be based on in-depth professional knowledge and command of one's field, it calls for attention to the present, insight and proportion. Ladkin (2008) calls this an aspect of mastery. 
Listening and formulating an aesthetic judgment are closely linked to each other. A conductor and music pedagogy once said, that the conductor is the defender of the composer, not the subjective interpreter of the musical piece (personal communication, Ropo). This observation emphasizes another relational aspect and aesthetic judgment in symphony orchestra leadership: relationship with the music beyond the interpersonal relationships.

Conducting and playing an instrument are bodily actions, which calls for mastering both the instrument and the music connected to the bodily movements in an intended way, beyond the intellectual and cognitive skills. Gestures and movements are indicators of the physical embodiment of aesthetic leadership in orchestras (Bathurst and Cain, 2013). Also here the relational aspect of leadership is pointed out. It is not only the conductor's gestures with the baton, her bodily movements and facial expressions, but also the embodied ways of musicians to lean toward each other, onwards, backwards or side-wards along the music and sensing the movements of fellow musicians which make orchestra leadership both aesthetic, relational, but also a collective effort. Relying on Parviainen (2003), Koivunen and Wennes (2011) use the term "kinaesthetic empathy" (62) to describe various embodied aspects of aesthetic leadership. One distinctive feature in an orchestra is the fact that the players sit very closely to each other. You can practically hear and feel the breath of a colleague in your neck or cheek, smell physical odors and sense others' bodily movements. Someone has called this "working in the spitting distance" (personal communication, Ropo). This kind of a setting that continues day after day years long calls for a special bodily tolerance. 


\section{Example 2: Aesthetic leadership in theatre}

Leading a theatre performance

Being a rather special setting for leadership, theatre and theatre work have been an inspiration to the leadership field (Biehl-Missal, 2010) and provided metaphors to analyze and describe organizations in general (Mangham and Overington, 1987).

"As a theatre director you are working in an energy space drawn between order and chaos. You need to have a plan and focus on what you want to work with, but you need as well to allow for exceptions without loosing the big picture (overview)...

As a director I am ahead of the actors and other artistic staff when we start to work. Usually I have been working with the play at home half a year, while the actors had a première of another play. Often they haven't even read the script, which is not ideal. Then you have to engage and be present. In the start of a reading stage, I reserve time for each actor for their role and the story and devote my time and attention to them fully. I start to infuse their thinking and acting on what I would like to achieve with the situation or role, because a role can be played in so many different ways. We start getting to know each other, of great importance in the theatre world, but not elsewhere.

A special thing with theatre work is the common goal; the première, a fixed day planned early and which seems far ahead when you start working with the play. Everybody in theater has this reflex or focus integrated in their bodies, making them work intensively towards the première. This is very ingrained in us, we always deliver 
on time, it is very rare to hear about postponing a play or delay. I have only experienced it once in my life...

Another typical characteristic of theatre work is the physical presence during rehearsals, you have to be there physically and engage with people, touch them. During the rehearsals there is a living communication with everybody present, practical work where we play and try to find out things together. I personally like to sit down with all the staff, from actors to sound and light designers and to have a direct influence on theme. I do not have any contact with them between the rehearsals, only if there is a conflict I speak with them between the rehearsals. I prefer talking to them face-to-face, not through mail or telephone. If something is perceived as difficult I go after them, ask them: why is it difficult? I like to be physically and emotionally present to the people I work with." (Theatre director Morten Borgersen, April 2015)

What does the above quote tell us about the leadership of creative work in theatre? A skilled, renowned theatre instructor in Norway, working as a freelancer for different theatres, describes creative theatre work as a project towards a common goal, fulfilling the director's vision about the play, following certain 'unwritten' rules, but also as a highly people dependent, interactional and physical, aesthetic collective effort. Theatre work is embedded in a long historical tradition in the westernized world (Biehl-Missal, 2010), ingrained in professionalized culture where creative work modes are transmitted from generation to generation and finally in a calling and devotion to theatre as art. Because theatre work is people dependent and collective, its creative work processes and leadership are also highly relational. 
Theatre art is in itself a live performance here and now, an expression of people, speech, feelings, bodies and senses on stage. Theatre is a physical manifestation of art, where the aesthetic and emotional creative work is essential to achieve a play that engages and touches the audience's sensitivity. Creative theatre process with no emotions, neither positive nor negative, tends not to perform well (Sauer, 2005). Even destructive emotional forces have been found to be functional and important for theatre leadership (Sauer and Ropo, 2006). The emotional aspect is closely connected to bodily expressions in theatre.

Theatre work and its leadership are highly emotional, physical and aesthetic. Theatre performances have to be personalized to be interesting, true and good. Each person on the stage personalizes their perception of the role. The Stanislavski tradition in theatre is based on that the actor searches her inner self, her feelings and bodily sensations to perform a given role (Ladkin and Taylor, 2010; Taylor, 2012).

In many ways, theatre work and its leadership are a lot about getting people to work well together, to get the flow and team spirit. The work on stage conveys engagement, embodied playing and emotional 'nerve'. The interviewed director referred to this while describing that he engages actively in conflicts or misunderstandings amongst the creative ensemble. Enduring conflicts may easily destroy a creative process, but a harmonic work process is not an end in itself, as shown in the next example with reference to earlier studies (Sauer, 2005; Sauer and Ropo, 2007). The interviewed director indicated that theatre work is by no means democratic, but led by an artistic director who is responsible for the final performance - and still very much dependent on the interaction between the director and the actors. Interestingly, another theatre 
professional who has worked both as a theatre director and a manager of a major theatre described theatre work as being highly empowering and positive, allowing people to express their opinions and ideas.

"Theatre work is ingrained in a 'yes-culture', which means that initially everything is allowed. It is important for people in theatres to know that they can propose even the craziest idea; that you are allowed to think freely and propose creative suggestions. In the end, very few of these initiatives come through, either because there is no budget for it or because it is a bad idea. The importance, however, is to say yes, to encourage people to engage and relate."

(Theatre director Oslo Nye, Cathrine Telle, February 2013)

Leading by gaze and shame in theatre

Sauer and Ropo (2007) studied theatre rehearsals through an aesthetic leadership lens. They used the concept of gaze originally introduced in the film theory. There is a difference between looking and gazing: a look is a perceptual model open to all, while gaze is a mode of viewing, reflecting a cultural code. Gaze is also used to describe a gendered way of looking, a code of desire. Nowadays it is more commonly used by media theorists to refer both to ways how people look at each other and how this looking is described in visual texts. Sauer and Ropo studied empirically in one play rehearsal process how gazes were cast between the director and the actors. They were especially interested in how the actors experienced the director's gaze and how they responded to that in their artistic work.

The analysis concludes to four visual narratives that depict different ways of gazing 
and relating. The following pictures show how the different gazes looked like.

Insert Figure 1 about here

The "Monster" gaze was felt demanding, sharp, like piercing to the heart. The "Elitist" gaze was felt ironic, distant and undermining while The "Family" gaze on the contrary was experienced warm, friendly and encouraging and the "Tea party" gaze as calm, polite, even reserved and detached. The analysis ends to a matrix describing the dominant emotions (fear and safety) involved in the narratives on the one hand and the artistic and economic outcome of the play on the other hand. Interestingly, the study shows that both the demanding Monster and the encouraging Family led to positive outcome of the play whereas the ironic Elitist and the polite Tea party resulted in a negative outcome of the play.

Sauer and Ropo explain the findings by reflecting that while the Monster demanded a lot from the actors and created an atmosphere of fear, the actors put all their energy to even exceed the expectations despite the physical pain and mental humiliation they experienced. In another analysis of the same data Sauer and Ropo (2006) describe emotional paradoxes in a creative process in theatre. They show how shame experienced by the actors can serve as a positive trigger toward high performance and experience of professional development. These rather controversial findings in the context of leadership that is typically viewed as a positive force suggest that aesthetics has a strong emotional power both for the good and the evil. A common building block of the humanly questionable leadership of the Monster character was the actors' unconditional trust on the director's professional expertise. The director was known of his unconventional rehearsing practices, and the actors took some kind of pride to excel 
with him. The use of negative emotions may not be a norm or something to be commended even in the art world. However, the example shows that artistic work involves a broad range of emotions and aesthetic qualities. The artists may be better equipped by their training to relate to negative emotions than people in regular work organizations.

It is quite easy to understand that the Family leadership empowered the actors with warm gazes and encouragement. Under the ironic gaze of the Elitist the actors felt betrayed and fear because they experienced of being left alone without the director's support and advice. According to Sauer and Ropo study (2007), the polite gazes of the Tea party leadership resulted in a rather routine outcome with hardly any artistic or economic surprises; it was "business-as-usual" where the actors felt safe but not especially excited about their work.

\section{Example 3: NZTrio as curators: Aesthetic leadership by preserving and disrupting the canon}

(This part has been reorganized to better fit with the rest of the ms)

NZTrio have been working together professionally for over 12 years since their formation in March 2002. One of their objectives is to perform new music whether that is by local composers or offshore. They are known for commissioning works and in 2012 were awarded the prestigious KBB/CANZ (Composers Association of New Zealand) Citation for Services to New Zealand Music. This award is a significant honor within the Aotearoa New Zealand context and reveals a trio that courageously invites the public to hear new and challenging work. It is much easier to fill concert venues with music by the ever-popular Beethoven and Schubert than relative unknowns like Jane Brockman and Friedrich Schwertsik. Yet each 
concert NZTrio perform contains music that will be premiered at that concert or have been performed only once or twice previously.

Each concert contains music from the established repertoire and new works. They write of themselves on their website that "Every NZTrio performance is an intimate, dynamic and engaging ride - sometimes calm and tranquil, sometimes wild and intense" (NZTrio, 2015). This way of programming gives insights into how the Trio are leaders, in that they seek to influence and inspire audiences rather than compromise to suit to specific stakeholders. There is no sense of apology or even conceding to preferred tastes. By attending their concert audiences know that they will be confronted with uncomfortable and sometimes disturbing sensations as well as being consoled by known music.

Howard (1996) draws a distinction between leaders who seek common ground with followers and in the process compromise on many fronts to suit their environment, from artists, who on the other hand, do not compromise because their agenda is to create works of art that provoke and challenge. Artists do not "tailor" their ideas to suit the prevailing logics of the time (p. 22)

Indeed, the NZTrio website goes further to say that, "They smash old preconceptions of classical music being stuffy and ostentatious by presenting it in a fresh and approachable way" (NZTrio, 2015, emphasis added). This is not the language of a compromising leader but one of ensuring artistic integrity and a desire to inform and educate their publics.

The disruption of the canon was shown in the program of a concert in Auckland (September 20, 2015) that contained three works. The first was by Frédéric Chopin - g minor Op 8, which he wrote as an 18-year-old in 1829. This work is full of pianistic riffs that became recognized as 'Chopinesque', and it delighted the audience. The final work of that evening was by Camille Saint-Saëns - No. 2 in d minor Op 92 composed in 1892. In contrast to the first 
piece, the composer wrote this in his maturity and it puts technical demands on all the three players. The concert closed with a standing ovation from the audience of 300 (the concert venue was at its maximum seating capacity). Both these works gave the public an opportunity to hear music by well-known composers, and are standard fare for piano trios.

Sandwiched between those works was a commissioned piece by David Hamilton entitled "The Faraday Cage" composed in 2015. This work has allusions to a wire mesh device that, according to the program notes "distributes electrostatic charges around the exterior of the cage". The composer uses the notes C-A-G-E at the beginning of the final movement to complete the allusion of the metal construction. The juxtaposition of a scientific process with art making gave the opportunity to conceive one's world somewhat differently. One could question the 'cages' that encase in life and how those conceptual frames may constrain but also protect against direct attack by an outside force. To organizational scholar this prompts to contemplate the bureaucratic iron cage (DiMaggio \& Powell, 1991) and its constricting and liberating potential, opening new conceptions of that metaphor.

Performing music of this kind is a risk and the Trio manage that by clever programming. Yet they demonstrated an enthusiasm for new compositions, regardless of the technical demands that these would place on them and the aesthetic requirements placed on audiences. Speaking to the New Zealand Herald music critic, William Dart, David Hamilton said:

"One of the joys of writing for NZTrio was that you know they can damned near do anything, so this was an open invitation to give them something that will show them off really well and have a great musical experience" (Hamilton in Dart, 2012). 
This comment reveals a keen desire on the part of the composer to connect with the performers. In curating Hamilton's work, the Trio reveal a willingness to support the composer's intentions without restriction. This offers insights into leadership within arts organizations, especially when the artists themselves are the leaders.

The technical requirements for chamber music musicians are very great. They must necessarily have superior individual performance skills so that the instrument is fully under their control. In a small group, there is no place to hide and musicians must be continually at the height of their powers in order to successfully realize difficult compositions. Furthermore, when they come together, the ensemble demands are huge. The give and take of performing in the moment requires the ability to read subtle gestures and to listen to nuances within each other's playing. The teamwork is intense, as Murnighan and Conlon (1991) explore in their study of British string quartets. Understanding each other's function, and with supreme diplomacy encouraging each other to perform to their best, is a constant demand. All this takes place before the group is on stage performing for the public.

In sum, NZTrio perform their leadership function as caretakers of the canon. In this way they are curators, a contemporary function that is derived from the Latin word curare, which literally means to 'take care'. Curators traditionally are found in the art galleries where they organize displays in ways that protect the integrity of the works and guide the public through the gallery in some kind of a coherent experience. They may advocate for particular artists and prompt the viewing public to appreciate and indeed purchase the artists' works. In the widest sense of the term, curators are leaders in that they guide and influence the public to appreciate works of art. But whom are they leading? And what is their duty of care?

Although this may seem quite straightforward, the claim that curators are leaders hides significant problems. If their goal is to bring to the public's attention works of art that are 
readily saleable, they may either unwittingly or deliberately hide from the public, works that they deem of little interest. In this way they act as "gatekeepers" (Martorella, 1990, p. 4) by supporting works and artists that are in vogue, while rejecting those that would likely cause opprobrium. But the curator-as-gatekeeper denies the important leadership function of awakening the public to new ways of knowing the world through art that might be disturbing and difficult to approach. Indeed to shield the public from new and challenging work denies the leadership role that they are given.

Educators are conscious of the tensions while helping students know the traditions of works of art; they preserve the canon. Yet they also recognize the need to disrupt established preferences by offering works for study that lie outside the generally accepted corpus. Thus as Cherry-McDaniel and Fisher-Young (2012) claim, the canon is enriched when it is troubled and complicated. The process of disruption is not, however, destructive. Rather, it enriches and develops a field (Rand, 2013), and even emancipates people from the constraints of fixed views.

A curator similarly both preserves the canon by giving access to the public to important works, and disrupts it by promoting new works that may not gain immediate popularity. Here their duty of care is taking a leadership role in alerting the public to significant pieces that may or may not become canonical. These new works may appear only for a season, but during that time they offer critical reflections on those works that are held as canonical. This is the case with NZTrio. 'Curator' is not usually applied to performing artists, yet this is the term we use here to speak of NZTrio. They are caretakers of the heritage of classical piano trio music and promulgators of new music, especially that of composers and their home country, Aotearoa New Zealand. 


\section{Conclusions}

In this chapter we have looked at leadership in a creative context, the arts. Leadership in the arts calls for a deep understanding of the nature of the artistic work. Most often both the leaders and the followers are artists. The art world has long been under economic pressure globally and demands to contribute to the larger society have intensified. Managerial principles and practices have been increasingly introduced to the art world. Beyond these, leaders in the art world need to have specific expertise: they need to know their discipline, whether it is playing an instrument or rehearsing a play, thoroughly with all the nuances. Also, expertise in serving different audiences is called for while not compromising the artistic ambitions.

We think that leading creative artistic work would need a creative way of practicing leadership. To explore leadership in this particular domain we turned to a recently emerged aesthetic leadership approach that emphasizes felt meaning, senses and emotions, and a relational interaction between the leader and the follower. Not only the artistic outcome is aesthetic, but also the process of leading toward it: a process that evokes feelings and is fully immersed in people relating to each other.

Our chapter discusses leadership in the arts through a limited number of examples. A greater variety of cases would definitely reveal more specifics of the field. However, our illustrations and related research point out a number of leadership aspects that are especially crucial when taking an aesthetic leadership approach in the arts context. Our first observation is that there are some paradoxes or controversies: Aesthetic leadership approach emphasizes a relational and collective effort. However, both in orchestras and theatres leader-centricity could be simultaneously sensed with a strong emphasis on collective action. In a symphony orchestra the conductor's heroic role is amplified in the concerts: he (typically a male) comes 
last to the stage with the audience applauding even before the performance, the conductor stands in front of the musicians, raises the baton, and off we go. The whole orchestra is following his slightest movements and gestures. This is how it seems in the eyes of the audience. However, even in the concert situation, the performance is a collective outcome that calls for an intense, sensuous relationship between the conductor and the players as well as among the players. Our examples show that this aesthetic relationship is more visible in the rehearsal practices than in the concert hall. As in orchestra, also in theatre the director's role is concrete and visible in the rehearsal process. But when the play reaches the premiere, the director becomes invisible: his job is done.

Another intriguing aspect involves emotions. Our theatre example shows that not only positive emotions lead to the best outcome. This may have to do with the nature of doing art: It is work with passion and emotions, own and others. Sometimes it calls for or invites even the deepest, darkest emotions to be put on the play in order to reach the highest level of artistic quality.

Embodiment is a central aspect of aesthetic leadership. This is the case also in the arts. Both leading and following takes place in and through the body. It starts with the physical presence. It would be rather difficult to play an instrument or act - or to do any other work for that matter - without the body being present. Even in today's virtual work and collaboration bodies do not disappear (De Paoli, Ropo and Sauer, 2014). Aesthetic leadership in the arts involves various embodied aspects. Beyond being physically and emotionally present, sensitivity to the environment and sensuous alertness to sounds, voices, rhythm and moods were found important, not to mention an empathetic attitude to mundane bodily functions of fellow colleagues. Doing things differently, challenging, and stretching the limits 
of the ordinary belong to leadership in the arts domain. Through aesthetic leadership this is done with body and mind entangled with each other.

Aesthetic leadership follows a relational approach (Ladkin, 2008; Uhl-Bien and Ospina, 2012) where the emphasis is on leadership constructed in mutually constituted relationships, whose quality is the key, not the individual competencies of the leader or the followers as such. Here, sensitivity to embodied experiences and sensuous perceptions are important as well as trustful relationships. We would like to summarize that there are specific issues in aesthetic leadership that both the leader and the followers in an artistic work process would need to attend to: First, reflexive awareness - being aware of the self vis-à-vis the other and how the self moderates in relation to the other - is important. Second, 'dwelling' in the senses - not dismissing the senses, not rationalizing them and acting outright. Springborg (2010) describes aesthetic leadership as something where leaders "stay with their senses". Third, interrogating the senses: what am I sensing, what do I see, hear, or escape from seeing or listening? How am I responding? And finally, finding spaces within the artistic process and sensing its rhythmic pulse with openings and closings: when to intervene, when to let be. This is an intimate relational process between the leader and the followers, a process where the formal positions may become redundant as the artistic flow keeps growing.

\section{References}

Barnard, C. (1938) The Functions of the Executive. Cambridge, MA: Harvard University Press.

Bathurst, R. and Cain, T. (2013). Embodied leadership: The aesthetics of gesture. Leadership 9, 358-377. 
Biehl-Missal, B. (2010). Hero takes a fall - A lesson from theatre for leadership. Leadership 6, $279-204$.

Cherry-McDaniel, M., and Fisher-Young, A. (2012). Complicating the canon: Disrupting what we know. English Leadership Quarterly 34, 8-11.

Dart, W. (2012). Emotional contact is essential Retrieved October 15, 2015, from http://www.nzherald.co.nz/entertainment/news/article.cfm?c id=1501119\&obje $\underline{\mathrm{ctid}=11516017}$

De Paoli, D., Ropo, A. and Sauer, E. (2014). Disappearing bodies in virtual leadership? In Ladkin, D. and Taylor, S. S. (Eds), The Physicality of Leadership: Gesture, Entanglement, Taboo, Possibilities. Bingley, UK: Emerald, 59-79.

DePree, M. (1989). Leadership is an Art. New York: Doubleday.

DiMaggio, P. J., and Powell, W. W. (1991). The iron cage revisited: Institutional isomorphism and collective rationality in organizational fields. In W. W. Powell, W. W. and DiMaggio, P. J. (Eds), The new institutionalism in organizational analysis. Chicago: The University of Chicago Press, 63-82.

Dinh, J. E., Lord, R. G., Gardner W. L., Meuser, J. D., Liden, R. C., and Hu, J. (2014). Leadership theory and research in the new millennium: Current theoretical trends and changing perspectives. Leadership Quarterly 25, 36-62.

Gagliardi, P. (1990). Symbols and artifacts: views of the corporate landscape. Berlin and New York: Walter de Gryuter.

Guillen, M. (1997). Scientific Management’s Lost Aesthetic. Architecture, Organization and the Taylorized Beauty of the Mechanical. Administrative Science Quarterly 42, 716-749. 
Guillet de Monthoux, P. (2004). The Art Firm: Aesthetic Management and Metaphysical Marketing. Stanford: Stanford Business Books.

Guillet de Monthoux, P., Gustafsson, C., and Sjöstrand, S. E. (Eds) (2007). Aesthetic Leadership: Managing Fields of Flow in Art and Business. London: PalgraveMacMillan.

Hansen, H., Ropo, A. and Sauer, E. (2007). Aesthetic leadership. Leadership Quarterly 18, $544-560$.

Hassard, J., Holiday, R. and Willmot, H. (Eds) (2000). Body and Organization. London: Sage.

Howard, V. A. (1996). The aesthetic face of leadership. Journal of Aesthetic Education, $30(4), 21-37$.

Katz-Buonincontro, J. (2011). How Might Aesthetic Knowing Relate to Leadership? A Review of the Literature. International Journal of Education \& the Arts, 12, Special Issue 1.3 - http://www.ijea.org/v12si1/

Koivunen, N. (2002). Organizational music: The role of listening in interaction processes. Consumption, Markets and Culture 5(1), 99-106.

Koivunen, N. (2003). Leadership in symphony orchestras. Discursive and aesthetic practices. Tampere: Tampere University Press.

Koivunen, N. and Wennes, G. (2011). Sow us the sound! Aesthetic leadership of symphony orchestra conductors. Leadership 7 (1), 51-71.

Ladkin, D. (2008). Leading beautifully: How mastery, congruence and form create the aesthetic of embodied leadership practice. Leadership Quarterly 19(1), 31-41. 
Ladkin, D. and Taylor, S. S. (2010). Enacting the true self: Towards a theory of embodied authentic leadership. The Leadership Quarterly, 21,64-74.

Ladkin, D. and Taylor, S. S. (2010b). Leadership as art: Variations on a theme. Leadership 6(3), 235-241.

Linstead, S.A. and Höpfl, H. J. (Eds) (2000). The aesthetics of organization. London: Sage. Mangham, I.L. and Overington, M. A. (1987). Organizations as theatre: A social psychology of dramatic appearances. Chichester: Wiley.

Martorella, R. (1990). Corporate art. New Brunswick: Rutgers University Press.

Murnighan, K., \& Conlon, D. E. (1991). The dynamics of intense work groups: A study of British string quartets. Administrative Science Quarterly, 36(2), 165-186.

NZTrio. (2015). NZTrio Retrieved November 26, 2015, from http://www.nztrio.com/

Parviainen, J. (2003). Kinaesthetic empathy. Dialogue and Universalism XIII (11/12), 154-165.

Rand, E. J. (2013). Queer critical rhetoric bites back. Western Journal of Communication, 77(5), 533-537. doi: 10.1080/10570314.2013.799285.

Ramirez, R. (1996). Wrapping form and organizational beauty. Organization. 3(2), 33-42. Ropo, A. and Parviainen, J. (2001). Leadership and bodily knowledge in expert organizations. Epistemological rethinking. Scandinavian Journal of Management, 17 (1): 1-18. Ropo, A., Parviainen, J. and Koivunen, N. (2002). Aesthetics in leadership. From absent bodies to social bodily presence. In Parry, K.W. and Meindl, J.R. (Eds), Grounding Leadership Theory and Research. Issues, Perspectives and Methods. Volume 1: Research in Leadership Horizons. Greenwich, CT: Information Age Publishing, 2138. 
Ropo, A. and Sauer, E. (2007). Corporeal leaders. In Barry, D. and Hansen, H. (Eds), The SAGE Handbook of New Approaches in Management and Organization. London: Sage, 469-478.

Ropo, A. and Sauer, E. (2007). Leading by gaze in theatre. Proceedings of the Art of Management and Organization Conference, Valencia, Spain.

Sauer, E. (2005). Emotions in Leadership. Leading a Dramatic Ensemble. Tampere: Tampere University Press.

Sauer, E. and Ropo, A. (2006). Leadership and the driving force of shame: A social constructivist analysis of narrative. In Zerbe, W.J., Härtel, C.E.J. and Askhanasy, N.M. (Eds), Individual and Organizational Perspectives on Emotion Management and Display. Research on Emotions in Organizations. Oxford, UK: Elsevier, 57-80.

Sinclair, A. (2005). Body possibilities. Leadership 1 (4), 387-406.

Soila-Wadman M. (2007). Can artists be leaders? Beyond heroic film directing. In Guillet de Monthoux, P., Gustafsson, C. and Sjöstrand S. E. (Eds). Aesthetic Leadership: Managing Fields of Flow in Art and Business. Hampshire: Palgrave Macmillan, 7286.

Springborg, C. (2010). Leadership as art - leaders coming to their senses. Leadership 6 (3), 243-258.

Strati, A. (1989). Aesthetics and Organizational Skill. In B. Turner (Ed.) Organizational Symbolism. New York: De Gryuter.

Strati, A. (1992). Aesthetic understanding of organizational life. Academy of Management Review 17 (3), 568-581.

Taylor S. S. (2012). Leadership craft, leadership art. New York, NY: Palgrave. 
Taylor, S. S. and Karanian, B. (2008). Working connection: The relational art of leadership. Aesthesis. International Journal of art and aesthetics in management and organizational life, 2 (2), 15-22.

Uhl-Bien, M. and Ospina, S. M. (Eds) (2012). Advancing Relational Leadership Research. A Dialogue Among Perspectives. Charlotte, NC: Information Age Publishing.

Vaill, P.B. (1989). Managing as Performing Art. San Francisco: Jossey-Bass.

White, D.A. (1996). 'It's working beautifully!' Philosophical reflections on aesthetics and organization theory. Organization, 3 (2), 195-208.
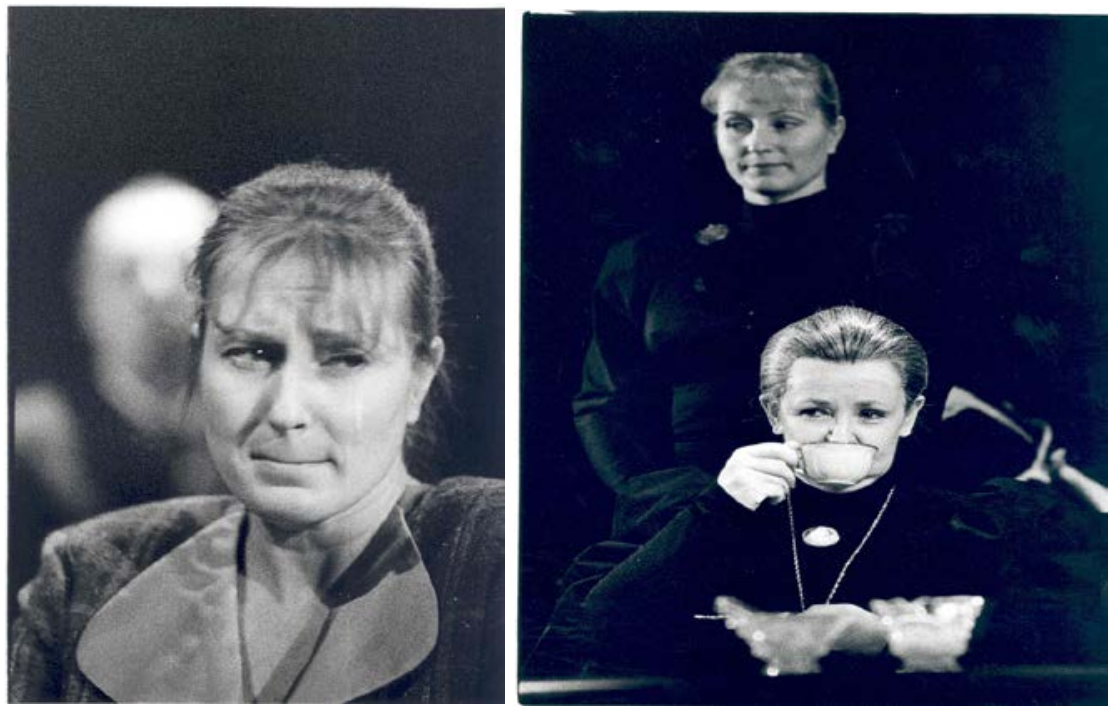

Monster

Elitist 


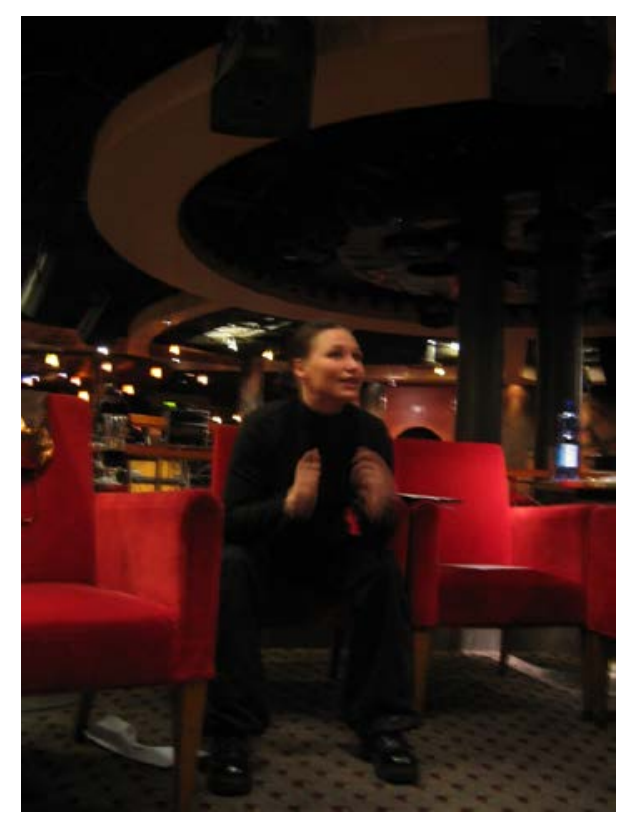

Family

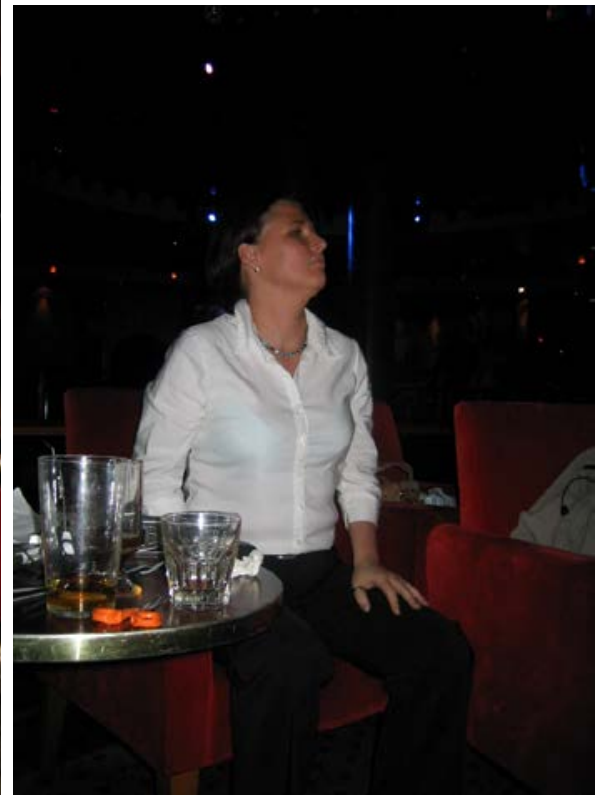

Tea Party

Figure 1. Leading by gaze: Monster, Elitist, Family and Tea Party 